\title{
Konsumtion som vardaglig praktik och ideologiskt slagfält
}

\author{
ORVAR LÖFGREN
}

\begin{abstract}
All diskussion om konsumtion är moraliskt laddad, vilket gör forskningen kring vår egen (och framförallt andras) köplust till ett minerat fält. I den nya tvärvetenskapliga kulturforskningen kring konsumtion finns ofta en nuets hemmablindhet som överbetonar vissa aspekter av vaira liv som konsumenter och ignorerar andra. Artikeln diskuterar några möjigheter att fä bättre balans $i$ studiet av konsumtion som både vardaglig praktik, dagdröm och ideologisk
\end{abstract}

arena.

\section{Homo consumans}

Det var under 1980-talet som yuppie-figuren uppfanns i södra Kalifornien och snabbt blev symbolen för tidens stora köpfest och överkonsumtion. Detta var decenniet då Madonna konstaterade att hon var "a material girl«, men det var även en tid då konsumtionen kom i fokus för en rad vetenskapliga discipliner som tidigare ägnat ett mera förstrött intresse åt detta fält. Nu möttes antropologer, etnologer, kultursociologer, me-

Orvar Löfgren är professor i etnologi vid Lunds universitet. Han har de senaste åren lett ett forskningsprojekt kring "Välfärdsdrömmar och vardagsliv - konsumtionen i efterkrigstidens Sverige", finansierat av HSFR. diaforskare, litteraturvetare, socialhistoriker och andra i ett gemensamt intresse för konsumtion som kulturellt fenomen. Det nyvaknade intresset speglade förvisso 1980talets köpfest, men var framförallt en reaktion mot en tidigare konsumtionsforskning.

Ordet konsumtion har alltid haft en dålig klang - dess ursprungliga betydelse: förtärande, förgörande, förstörande, har ofta stått som den destruktiva motsatsen till det konstruktiva som läggs i begreppet produktion, som då fått representera skapande, kreativitet, förmering och allmän nyttighet. Produktion står ur detta perspektiv ofta för det aktiverande, medan konsumtion får symbolisera det passiviserande.

Samma problem finns i 1900-talets 


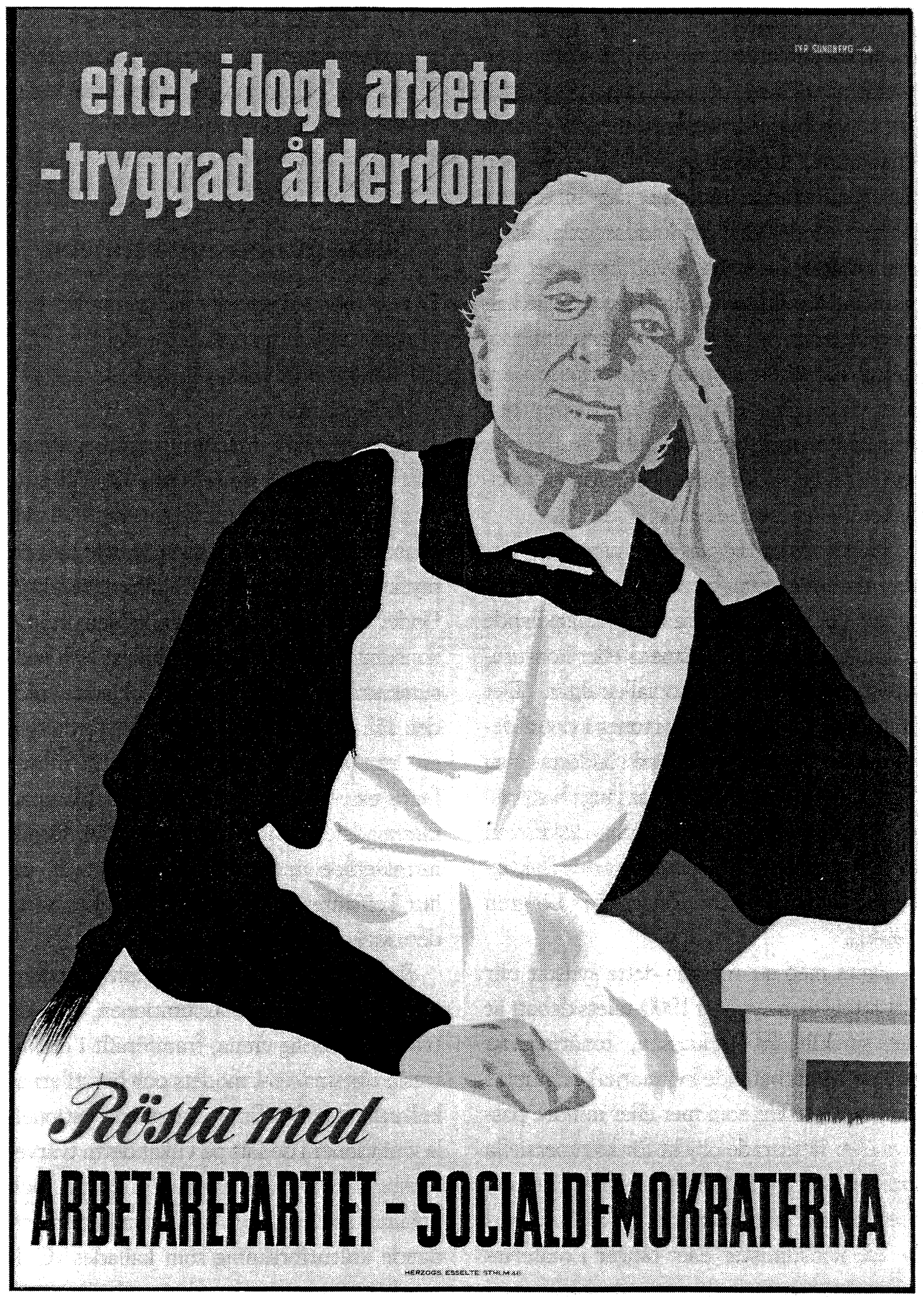

Löfgren - Konsumtion som vardaglig praktik och ideologiskt slagfält 
många diskussioner om "homo consumans" - den konsumerande människan - ofta definierad som en ny människotyp, vars identitet är uppbyggd kring konsumtion. Gamla etablerade, trögrörliga, rutiniserade och lågkonsumerande livsformer sägs bli ersatta av mer mode- och marknadsstyrda, "konsumistiska» livsstilar. Ofta finns det ett markant devolutionistiskt perspektiv i denna diskussion, ett antagande om att den moderna homo consumans representerar en förflackad, modepräglad, mer ytlig och fragmentariserad personlighet. (Nej, annat var det förr: då fanns det helgjutna personligheter eller fasta socialkaraktärer!)

På detta sätt kopplas den marknadsstyrda människan ofta samman med föreställningar om den teatraliska, rollspelande människan: en kapitalismens eller konsumtionssamhällets nya socialkaraktär. Det finns ofta ideologiska övertoner i detta devolutionistiska perspektiv på sönderfall och desintegration, som alltså har långa historiska rötter. Dagens postmoderna diskussion av disintegration, fragmentering och flyktighet har alltså sina föregångare (jfr Löfgren 1994a).

Faran med att renodla detta synsätt blir lätt att vissa grupper (i 1900-talets debatt är det särskilt arbetarklassen, tonåringarna och de hemarbetande kvinnorna) definieras $i$ termer av offer, som mer eller mindre passiva eller lättlurade objekt för kommersiella krafter. Under 1980-talet blev det ofta östeuropeerna som beskylldes för att vara lättlurade konsumister eller fångar i materialismens garn. Det visar sig att både samhälls- och forskningsdebatten kännetecknas av ganska traditionsfasta genrer. I klagomålen över ungdomens lyxkonsumtion mot 1700-talets slut kan vi urskilja en argumentationsteknik som går igen i diskussionen av första världskrigets gulaschbaroner eller 1980-talets karikatyrobjekt, yuppien.

\section{Den nya konsumtionsforskningen}

Det är mot bakgrunden av denna tidigare syn på konsumtion som en passiviserande, nivellerande kraft som vi måste förstå 1980talets nyorientering.

I Sverige hade man i mycket begränsad omfattning ägnat sig åt detta fält tidigare. Den sociologiska subdisciplin som kallades konsumtionssociologi hade i Sverige haft en mycket pragmatisk och tillämpad karaktär. Under 1950- och 60-talen knöts den ofta till konsumtionspolitiska utredningar och konsumentrådgivning. Teoriutvecklande blev den sällan och under 1970-talet förde den en mycket tynande tillvaro. Därutöver fanns en omfattande och mycket tillämpad marknadsföringsforskning, som framförallt intresserade sig för frågor som: när, var och hur konsumerar människor (och kan vi få dem att konsumera mer)?

Det nya var att det nu var kulturforskarna som grep sig an konsumtionen, som en tvärvetenskaplig arena, framförallt i ett intresse för smakens, modets och livsstilarnas kulturanalys. Det finns intressanta nationella variationer i de sätt på vilket detta tvärvetenskapliga fält koloniserades: i USA och England kom den typ av disciplinöverskridande kulturforskning som kallades "Cultural Studies« att få en central placering. Om den moderna sociologin växte fram som arbetslivets, organisationernas och samhällsplaneringens disciplin, så har Cul- 
tural Studies varit konsumtionssamhällets barn (jfr Löfgren 1994b).

Den nya konsumtionsforskningen växte fram, dels i en tid då symbolteori, från strukturalism till semiotik stod starkt, och dels i en period då marxistiskt och maktteoretiskt intresserade forskare i sitt sökande efter ett aktörsperspektiv snarare än det väletablerade strukturperspektivet började analysera konsumtion, fritid och ungdomskultur i termer av kulturellt motstånd. Detta var en mer eller mindre gramscianskt färgad fokusering på konsumenten och mediaförbrukaren som en den dominerande kulturens guerillamotståndare, som kreativt, approprierar och transformerar snarare än imiterar och anpassar sig (jfr Harris 1992). Lite elakt kan man säga att varje alternativt bruk av en flaska Coca-Cola lätt kunde ses som subversivt och heroiseras i termer av motstånd. Denna typ av trivialisering möter vi t ex i kultursociologen John Fiskes diskussioner kring "konsumtion som kollektivt motstånd (jfr Fiske 1989 a och b).

Detta fokus måste dock i ärlighetens namn ses som en del av de pendelslagens förbannelse som präglat mycket av forskningen på detta fält. Bilden av den kreativa konsumenten har en mottext i den tidigare forskning jag kort skisserat - $\mathrm{i}$ bilden av konsumenten ohjälpligt snärjd i kommersialismens garn. Här finns problemet med att nå en balans $\mathrm{i}$ att analysen av konsumtion från två ytterlighetspunkter: som emancipatoriskt motstånd och kreativ frigörelse å ena sidan, och passiv förförelse och marknadsmanipulation å den andra.

\section{Upptrampade stigar}

Om man alltså kan säga att 1980-talets nya konsumtionsforskning var en reaktion mot överdrifter i en tidigare forskningstradition, så skapades även här efterhand vissa skygglappar. Somliga stigar och studieområden kom att bli mer upptrampade än andra. Konsumtionen analyserades utifrån symboliska och semiotiska perspektiv. Grundmetaforen blev att »läsa" kulturen och perspektivet var ofta medialt. Detta konsumtionsteoretiska intresse förstärktes av den postmoderna teoribyggenas intåg i kulturforskningen. Det var köpcentret, souvenirsamlingen, tonårsrummet, punkklädseln som kunde läsas som en text eller snarare som ett knippe texter: överlagrade, fragmenterade, motsägelsefulla.

Även om detta avläsande av kulturen visat sig vara en trång och endimensionell metafor för vardagskulturens mångsinnlighet, så har de postmoderna perspektiven inom kulturforskningen inneburit en vitaliserande utmaning, just genom sin ifrågasättande och dekonstruerande kraft.

Den nya konsumtionsforskningen tog framförallt formen av ungdomskultursstudier. Följden är att vi vet en hel del om hur unga använder konsumtionen som ett laboratorium för identitetsspel: hur man testar klädsstilar och frisyrer, hur man kombinerar olika mediabruk, hyr en video, väljer ett diskotek, hänger utanför köpcentret, leker med ting och moden, hur man kommunicerar identitet genom ting och symboler som markörer. Det vi finner här är en speciell och åldersspecifik form av konsumtion, som betonar vissa former av förbrukande: konsumtionsaktiviteter med hög grad av expressivi- 
tet och visibilitet - det färgstarka och det spektakulära, men även det lustbetonande.

Samma tendens finner vi den livskraftiga forskningen kring shoppande, där möter vi ofta en betoning av dagdrömmens och begärets former, flanörens och skyltfönstrets interaktion. Återigen är det en betoning av konsumtion som symbolisk produktion, för att använda en talande metafor.

Med detta är jag inte ute efter att kritisera forskningen vare sig kring ungdomen eller köplusten - det är inom dessa vitala fält som mycket av ny kulturteori utvecklats och befruktat andra områden. Vad jag menar är att fokuseringen pà det symboliska har snedbelastat studiet. I undersökningar av konsumenter, tonåringar, hembyggare, och tevetittare känns det ibland som om man glider runt i en semiotisk skog av viskningar och rop, av meningar, innebörder, budskap.

Vart tar alla de andra sinnena vägen i studiet av människors konsumtion, deras fritid och vardag? Folk betraktar, beskådar, beser, begär och beundrar ju inte bara tingen utan rör vid dem, smakar, doftar på dem i ett ständigt samspel mellan sinnena (och inte minst då det sjätte). Folk inte bara tittar, kikar och blickar, de kånkar, släpar, donar, fixar, brukar, nöter, stöter, blöter, reparerar, underhåller, omskapar, stuvar undan, plockar fram, sliter och slänger, sparar och återbrukar alla dessa ting.

Vad vi möter i mycket av 1980- och 1990talets kulturforskning är en ganska omedveten och gradvis insnävring av konsumtionsstudiet. Här har man utgått från ett konsumtionsbegrepp som prioriterat vissa former för konsumtion, till detta fogat begreppet symbolisk kreativitet, som ytterligare begränsat fältet och så tillfogat en betoning av det okulära och det estetiska. Resultatet är att det är högst begränsade former av konsumtion och vardagsliv som överexponeras i det analytiska rampljuset. Det är tingen som texter, ikoner, budskap och symboler som hittills dominerat, men inte bara det: livet med tingen har även i hög grad blivit det lustbetonade, lekande och det kreativas arena. Den vardagsgrå och något mer oheroiska konsumtionen av långvård, busskort, elektricitetsräkningar eller släpandet på lättmjölk och oblekt hushållspapper från Konsum och Ica hamnar minst sagt i skymundan.

Vi har därför anledning att fundera mer över konsumtion som konsten att hushålla. Kanske har det faktum att det nya intresset för konsumtionsstudier startade i 1980-talets köpfest påverkat fokusering på konsumtion som nöje. Vad skulle ha hänt om de flesta av oss gett oss in på samma studiefält under det tidiga 1990-talets lågkonjunktur i en värld där familjer plötsligt ställdes inför att låta hela det drömprojektet som hette småhuset gå på tvångsauktion eller där arbetslöshet och galopperande räntor slog överflödsekonomin i spillror? Hade det medfört ett större intresse för konsumtion som hushållning med knappa resurser, konsumtion som återbruk eller försakelse? Då hade vi kanske fått en starkare markering av de sätt på vilka begäret, förvärvet och bruket av tingen skapar fördelningsproblem, när hushållets begränsade resurser av tid, pengar och emotionell energi ska fördelas i konsumtionen, när prioriteringar mellan det nödvändiga och det onödvändiga måste företas.

Detta är en aspekt som framträder i den amerikanska antropologen Katherine New- 
mans studier (1988 och 1991) av social och ekonomisk nedåtgående mobilitet, bland grupper som konfronterats med arbetslöshet och lönesänkningar i en ekonomi som alltid baserats på föreställningar om ständigt förbättrad köpkraft:

American culture has always celebrated forward motion, progress, upward mobility. We are true optimists, always assuming that the world-or at least our corner of it-will continue to provide more for us than it did for our parents, and more for our children than we have today. This central expectation dies hard. When reality fails to provide what we think we are owed, we seldom readjust our expectations. Instead, we stew in frustration or search for a target for our anger, pointing fingers at more fortunate generations, incompetent presidents, disloyal corporations. When this fails to satisfy, Americans are often inclined to look within, to personalize wide-scale economic disasters in the form of individual failings (Newman 1991:122).

Hennes analys berör framförallt de medelklassgrupper, som aldrig trott att de skulle ställas inför arbetslöshet eller lönesänkningar, och som nu genomgår den smärtsamma processen att lära sig hushålla med mindre, och få barnen att inse att de inte längre kan få vad de vill. Här möter vi arbetslösa chefstjänstemän som måste be sina fruar om fickpengar eller som kör långt bort för att handla mat, så att de inte ska riskera att grannar och vänner ser dem betala med socialvårdens matkuponger i snabbköpet. Det är helt nya konsumtionskompetenser som nu måste utvecklas.

Ett fokus på konsumtion som konsten att hushålla innebär även en kritisk granskning av de könsstereotyper som sett männen som producenter och försörjare, och kvinnor som konsumenter och förslösare.

Det finns många studier av den traditionella arbetsfördelningen i svenska arbetarmiljöer, där mannen oftast överlämnade veckolönen till hustrun. Det var hennes ansvar att hålla familjen flytande, att planera och budgetera i en hushållsekonomi med mycket små marginaler (jfr Arvastson 1988 och Wikdahl 1993). Vi skulle behöva liknande detaljrika analyser av denna hushållskonsumtionens mikrosociologi i dagens situation - vem köper vad, vem ansvarar för vad? Vilka generations- och klassskillnader kan vi finna här?

Studierna av konsumtion och fattigdom är fortfarande få. Här möter vi ett område som även utgjort ett ideologiskt slagfält inom socialvården. Jag tänker på de ändlösa debatter som under 1900-talet förts om socialbidragsnormer och levnadsstandard bland bidragsmottagare. Här möter vi ett centralt - och tidlöst - tema i konsumtionsdebatten: över- eller underkonsumtionens moral. Vad är lyxkonsumtion och nödvändig konsumtion? Gränserna mellan dessa kategorier har ständigt flyttats runt - de är kulturellt och socialt definierade. Mycket av det som för 1930-talets arbetarklass tedde sig som ouppnåeliga konsumtionsdrömmar hör idag till livets nödtorft. I den sociala nedrustningens 1990-tal möter vi en intensifierad debatt av definitionerna av rimlig levnadsnivå eller var fattigdomsstrecket ska dras. Vilken standard bör en flyktingfamilj, en förtidspensionär eller en arbetslös ha rätt att kräva? Ibland materialiseras dessa debatter i en symbolisk kamp över enskilda konsumtionsobjekt: bör man ha rätt till telefon, till färg-TV, semesterresa? Till denna diskussion knyts även en annan klassisk frå- 
geställning: kan de med små inkomster verkligen hushålla - är de mogna konsumenter? Hit hör historierna om bidragsfamiljer som lever på för stor fot, och i denna folklore finns flera traditionsfasta element, som t ex frekvensen vräkiga svarta skinnsoffor bland understödstagare. Denna möbel har i flera decennier fått symbolisera fel sorts konsumtion hos arbetarklassen.

Debatten kring socialbidrag och konsumtion kommer därigenom att fokusera på ett genomgående tema $i$ alla diskussioner av konsumtion, nämligen den känsliga frågan om rätt och fel sorts konsumtion - ett ideologiskt slagfält med lång historia, som påminner oss om att det finns ett moraliskt element $\mathrm{i}$ all debatt om konsumtion.

\section{Konsten att konsumera}

Ett annat sätt att få en bättre balans i konsumtionsforskningen vore att fokusera mer på konsumtion som kulturell kompetens: ett kunskapskapital som varje generation måste erövra utifrån olika förutsättningar. Hur blir vi konsumenter och vad måste vi kunna för att konsumera i det samhälle och den epok vi färdas igenom?

Konsumtionen tar stor plats i våra liv. Tingen ockuperar inte bara alltmer plats $i$ våra prylfyllda, bågnande garderober, leksakslådor, köksskåp och källarutrymmen: de tar tid och plats på mycket konkreta sätt, de fyller även vårt medvetande med överväganden om val och bortval, om bruk och förbruk, om inköp och kasserande.Tingen förenklar och försvårar ständigt vår tillvaro, de sätter oss på hårda prov när de väljer att gå sönder eller krångla. Det flesta av oss drivs med jämna mellan rum till raseriets eller tå- rarnas rand, när vi misslyckas med att omprogrammera videobandspelaren, sätta ihop IKEA-skåpet Princip, får motorstopp mitt på en skogsväg, feldoserar tvättmaskinen, bränner vid stekpannan eller snubblar på 367 utspridda legoklossar. Den holländske antropologen Jojada Verrips har diskuterat hur denna vår fascination och frustration inför tingen givit upphov till moderna former för animism: »The damn thing didn't do what I wanted it to do!" (Verrips 1994). Författarinnan Susanne Brögger har i suckandet inför livet med telefonsvarare, videospelare, faxar och mikrovågsugnar föreslagit att den framtida typfamiljen borde bestå av mamma, pappa, barn och en elektroingenjör.

Återigen ställs vi inför hemmablindhetens problem: det är lätt att se hur vilka färdigheter, vilken kulturell kompetens, en hantverkare eller en husmor behövde i 1800-talets bondehushållning, men hur ser motsvarande kompetens ut i dagens HSB-lägenhet, på kontoret, eller vid det. löpande bandet? En möjlighet är att åka rulltrappa med den amerikanske författaren Nicholson Baker:

Vilken tillverkare av sockerpåsar hade kunnat veta att folk skulle ta för sig att vifta av och an med påsen för att centrifugera innehållet till botten så att de behändigt kan riva av toppen? Det nakna i en enkel nyhet på portionsförpackningens område har omgärdats och mjukats upp och fått mening av en gestikulär anpassning...bekvämligheten har givit upphov till balett; och ljudet av de flaxande sockerpåsarna en tidig morgon, som ett fladder från närbelägna bås, är något jag ogärna vill avstå från, fast jag dricker mitt kaffe osötat. Ingen hade kunnat förutse att fastighetsskötare skulle stå stilla och putsa handledaren på rulltrappor, eller att skolelever skulle upp- 
täcka att man kan snärta iväg portionsförpackade smörtärningar så att de fastnar på väggen, eller att handelsmän skulle upptäcka att de bekvämt kunde stoppa pennor bakom örat, eller att de senare med tiden skulle sluta stoppa pennor bakom örat, eller att vindrutetorkare kunde tjäna som behändiga ställen att sätta flygblad på. En anspråkslös teknisk uppfinning - sugröret, sockerpåsen, pennan, vindrutetorkaren - har broderats ut av en stum folklore med uppfunna beteenden, oregistrerade, opatenteterade, anammade och finslipade utan en kommentar eller en tanke.

Denna och andra reflektioner kring vardagens liv med tingen återfinns i romanen "Rulltrappan" (Baker 1990:98). Den handlar om en rulltrappefärd mellan två våningar $\mathrm{i}$ ett kontorskomplex på Manhattan, en resa som används för väldiga tankeutflykter till vardagens materialieteter, rutiner, småting. Bokens hjälte hinner med att fundera över sugrörets evolution, dörrhandtagens taxonomi, skoknytandets motorik och mjölkkartongens mikrohistoria, uppfinningen av det perforerade toalettpappret och mycket annat, gärna då med hjälp av långa, akademiska fotnötter.

Själva författartekniken med ideliga digressioner, tillbakablickar och funderingar syftar till att problematisera och exotisera vårt vardagliga liv med tingen, men även att utforska hur vår livshistoria och våra minnen knyts till objekt, känslor och konsumtionshandlingar. Baker leker med denna Proustianska genre när han reflekterar över hur häftplåster brukade lukta när han var liten eller vilka TV-reklamer som fastnat $i$ minnet.

Bakers stil är etnografisk med en blandning av naiv nostalgi, akademisk parodi och en närmast postmodern ironisk distans som kan vara ganska svårhanterlig för läsaren. Ingenting är för trivialt för att det inte ska få sin kulturhistoria och mikrosociologi skriven, och i denna process antar småtingen nya dimensioner, samtidigt som den lilla och stora historien länkas samman. Baker hjälper oss att minnas alla dessa vardagsgrå och alltför självklara ting och rutiner som är själva grundstrukturen i våra liv. Han hjälper oss att lägga märke till den konsumtion som handlar om livets nödtorft, allt från avloppssystem och elektricitet till tvättmedel eller häftklamrar. Det är den småtråkiga och oheroiska konsumtionen som här får sitt hjälteepos skrivet.

\section{Att lära sig konsumera}

Bakers funderingar fokuserar även på hur vår kompetens som konsumenter ofta blivit till en tyst eller osynlig kunskap, den har naturaliserats till vanor, rutiner och reflexer. Hur har vi lärt oss knyta ett skoband, öppna en mjölkkartong, dechiffrera en musikvideo, inleda ett telefonsamtal, hitta ett schampo bland 40 varianter på snabbköpshyllan?

Det finns en svårutrotad föreställning om att livet med tingen var rikare och mer mångfacetterat $i$ en äldre allmogevärld. I denna självhushållets värld skulle vi som nutida och passiviserade konsumenter inte kunna överleva en vecka. Men lika uppenbart är det att 1800-talets torpare skulle få klara problem att hantera vardagen $i$ en HSB-lägenhet. Det handlar här inte om hur mycket kompetens, färdighet och handlag som behövs i olika miljöer och epoker utan snarare vilken sorts. I HSB-livet finns till exempel en mängd gradvist uppövade färdig- 
heter att göra saker och ting på samma gång. Bre en smörgås samtidigt som man snabbläser tidningen och hör på nyheterna med ett öra, dammsuga med påkopplad Walkman, tala i telefon medan man kör bil, se på TV och sortera tvätt samtidigt. Vidare innebär vårt nutida konsumtionsliv att en oerhörd mängd val och prioriteringar ska utföras varje dag: beslut om konsumtion, köpa, slänga, bevara och bruka. De är ofta så rutiniserade att de sällan upplevs som val.

En möjlighet att komma åt denna kunskap är att be människor berätta om sina liv som konsumenter.

Vi har alla lärt oss att konsumera, från den första mödosamma prioriteringen av vårt habegär i produktionen av önskelistor till julafton, i samlandet av filmstjärnebilder eller plastfigurer. Vi kan minnas lördagsvandringen till kioskens schlaraffenland eller familjeutflykten till det stora varuhuset. Vi har inrett våra första tonårsrum, fantiserat om den första mopeden, bilen eller egna lägenheten, begått vår första charterresa, diskuterat fickpengar och köpmoral med våra barn, avancerat vidare i hembyggarkarriären, snickrat samman äktenskapet eller tapetserat om familjen på väg mot pensionärslägenhetens slutmål.

Sådana konsumtionshistorier varierar naturligtvis med generation, kön och klass, liksom med positionen i livscykeln. Den livshistoriska framställningen ger ofta goda inblickar i kulturella läroprocesser. I det livshistoriska perspektivet understryks den gradvisa inskolningen i varusamhället: hur man blev konsument, bilägare, TV-tittare (jfr Löfgren 1992).

De tidiga minnena av vägen in i varusamnhället kan ofta ha en friskhet och dis- tans, som vår senare mer rutiniserande konsumtion saknar. Man kan minnas feststämningen när postorderkatalogen anlände och familj bänkade sig kring köksbordet för att beskåda utbudet. Man kommer ihåg de första spännande besöken i det stora snabbköpet: glasdörrarnas schwischande ljud, shoppingvagnens det kyliga ståltrådsnät mot barnkroppen, det berusande överflödet av färger, varor och val.

Uppväxtminnena handlar även om hur man lärde sig bli hembyggare via möblerande av dockskåpet eller det ivriga skissandet på det egna drömrummet, hur tonårsrummet blev ett laboratorium för att testa olika stilar och identiteter under timslånga sessioner framför spegeln.

\section{Privat och offentlig konsumtion}

Ett annat föga utvecklat forskningsområde rör kopplingen mellan privat och offentlig konsumtion. Antropologen Daniel Miller påpekade en gång $\mathrm{i}$ en diskussion i vilken stor utsträckning vi övertagit mycket av den konsumtionsteori som utvecklats i USA och överfört den till europeiska miljöer, där samspelet mellan stat, marknad och individ varit ett annat. Han menar att vi mer förutsättningslöst bör granska likheter och skillnader i 1900-talets konsumtionshistoria, där inte minst de nordiska länderna med sin starka koppling mellan offentlig konsumtion och välfärdsnationalism har skapat andra mönster.

I ett annat sammanhang har jag haft anledning att reflektera över vilken nationaliserande kraft som ofta legat i konsumtionen, i det sätt på vilket mer homogena livs- 
mönster, rutiner och vanor skapades bland svenska konsumenter under folkhemsbygget. I vilken grad och på vilka sätt har staten organiserat olika former för konsumtion? Hur har marknadens och statens kontroll och ägande fördelats?

Mellankrigstidens nya Sverige svetsades inte samman genom ideologiska programförklaringar utan genom nya former av gemenskap, beroende och lojalitet. Nationen materialiserades på sätt som idag kan te sig triviala eller självklara. Lite tillspetsat kan man säga att elektricitetsledningar och avloppssystem var viktigare element i det nya nationsbygget än flaggviftandet. De tråcklade samman landet och skapade mycket konkreta former för delaktighet. På medborgarskapets grund växte det fram en allt större arsenal av gemensamma svenska roller: man blev motboksinnehavare, folkpensionär, skolbarnsförälder. Man möttes i inlärningen av nya svenska kompetenser: lärde sig svära över deklarationsbesvären varje februari, se fram emot industrisemestern i juli, ansöka om bosättningslån och svara på hälsoenkäter (jfr diskussionen i Ehn, Frykman \& Löfgren 1993).

Låt mig bara ge ett exempel på det sätt som staten och nationen materialiserades $i$ vardagens konsumtion. Under femtiotalet bodde jag om sommaren $i$ en halländsk kustby, där de flesta hushåll ännu saknade telefon. Uppe vid bygatan låg telefonstationen, ett pampigt funkishus, bebott av två telefonfröknar och med den krönta, blå skylten RIKSTELEFON vid ingången till trädgården. Jag minns fortfarande den speciella högtidliga stämning som spred sig när någon av telefonfröknarna kom cyklande i fladdrande sommarklänningar för att lämna be- skedet att familjen kunde vänta ett rikssamtal från Stockholm om en halv timme. I god tid vandrade vi förväntansfyllda upp för grusgången, rättade till kläderna och trädde in på expeditionen, som präglades av en mycket svensk sparsmakad och statlig estetik med spottkopp i hörnet och prydligt uppsatta exempel på lyxtelegram på väggarna. Det fanns en omisskännelig doft av rikstelefoni, av nationalstat, inom dessa väggar, på samma sätt som de trevliga telefonfröknarna inte bara var servicefolk utan statstjänare, precis som postfröken i huset bredvid och stinsen nere vid järnvägsstationen.

I all sin vardaglighet gjorde sig nationalstaten ständigt påmind i dessa situationer på ett stillsamt men ytterst konkret sätt. Att resa med Bröderna Anderssons bussbolag in till Varberg var en annan slags upplevelse än att gå ner till stationen och köpa en biljett till Statens Järnvägar. Vad betyder det att få ett rikssamtal, att gå på en offentlig badinrättning eller att lyssna till riksradion? 1990-talets ofta upphetsade debatter om privatisering av traditionellt statsliga verksamheter visar även hur laddat detta tema är, på ett sätt som inte kan reduceras till frågor om lönsamhet eller organisationsformer. Inställningen till och graden av statligt engagemang $i$ konsumtionen har växlat starkt mellan olika nationer och epoker samt även mellan olika klasser.

I Sverige har vi haft en speciellt stark koppling mellan stat och marknad när det gällt boende: $i$ välfärdssamhället intresserade sig myndigheterna inte bara för planering av bostadsområden utan även för vardagsrummets estetik och diskbänkens placering (jfr Löfgren 1993a, Linde-Laursen 1993). 


\section{Köplustens metamorfoser}

Under de senaste årtiondena har konsumtionsforskningen expanderat starkt, men det är en tillväxt som varit ojämn. Jag har pekat på några områden som blivit styvmoderligt behandlade i denna nya kulturforskning och argumenterat för närläsningar av vardagens konsumtionsmönster. Denna närläsning måste kopplas till ett historiskt perspektiv, som visar hur gränserna för våra konsumtionsbegär ständigt flyttas. Utopier visar sig uppnåeliga, det exklusiva och exotiska förvandlas till allmängods och vardagsmat, lyxen blir nödvändigheter, och längtan kan förvandlas till leda eller nya drömmar.
Processer som dessa påminner oss om att konsumtionens böjningsmönster formas av spännande glidningar mellan en rad verb: att sakna, önska, längta, begära, behöva, förvärva, äga, bruka, samla, exponera och förbruka. Kopplingarna och transformationerna mellan dessa led är aldrig givna utan kulturskapade - historiskt betingade och föränderliga. De har dessutom ett moraliskt och värderande inslag. Varje generation lär sig att konsumera utifrån de egna, tidsgivna förutsättningarna. Konsumtionsbekymrens vardagliga trivialitet är skenbar: här konfronteras samhällsideologier om rätt och riktigt, nödvändigt och onödvändigt, vulgärt och förfinat, högt och lågt.

\section{Litteratur}

Arvastson, Gösta (1988) Maskinmänniskan. Göteborg: Korpen.

Baker, Nicholson (1988) Rulltrappan. Sthlm: Legenda 1990.

Ehn, Billy, Frykman, Jonas \& Löfgren, Orvar 1993 Försvenskningen av Sverige. Det nationellas förvandlingar. Sthlm: Natur och Kultur.

Fiske, John (1989) Reading the popular. Boston: Unwin Hyman.

Fiske, John (1989) Understanding popular culture. Boston: Unwyn Hyman.

Harris, David (1992) From Class Struggle to the Politics of Pleasure. The Effects of Gramscianism on Cultural Studies. London: Routledge.

Linde-Laursen, Anders (1993) "The Nationalization of Trivialities: How Cleaning Becomes an. Identity Marker in the Encounter of Swedes and Danes."Ethnos, 1993:3-4:275-293.

Löfgren, Orvar (1992) "Mitt liv som konsument. Livshistoria som forskningsstrategi och analysmaterial«,i Självbiografi, kultur, liv. Levnadshistoriska studier inom human- och samhällsvetenskap, red. av Christoffer Tigerstedt, J.P.Roos och Anni Vilkko, Symposion, s 269-288.

Löfgren, Orvar (1993a) "Swedish Modern. Konsten att nationalisera konsumtion och estetik." Kulturstudier (Center for Kulturforskning, Aarhus University), 17:159-180.

Löfgren, Orvar (1993b) "Materializing the nation in Sweden and America",Ethnos 1993:3-4:161-196.

Löfgren; Orvar (1994a) „Consuming interests", i Jonathan Friedman (ed), Consumption and Identity, Langhorne:Harwood, s 88-110. Löfgren, Orvar (1994b) „En akademisk trettioårskris? Om rutiniseringen av Cultural Studies",Kulturella perspektiv, 1994,3:43-51.

Newman, Katherine S. (1988) Falling From Grace: The Experience of Downward Mobility in the American Middle Class. New York: The Free Press.

Newman, Katherine S. (1991) „Uncertain Seas: Cultural Turmoil and the Domestic Economy“ in A. Wolfe (ed) America at Century's End. Berkeley: University of California Press.

Verrips, Jojada (1993) „The damn thing didn't do what I wanted it to do!» I J. Verrips (ed), Transactions. Essays in Honor of Jeremy F. Boissevain, Amsterdam: Het Spinhuis, s 35-52.

Wikdahl, Magnus (1993) Varvets tid. Stockholm: Gidlunds. 


\section{Summary}

\section{Consumption as everyday routine and ideological battlefield}

Th paper presents an ongoing project on consumption in Sweden, with an analysis carried out on three dvels, looking at consumption as everyday praxis, as daydream and utopia and as an ideological arena, here almost any statement about consumption has a moral message.

The cultural analysis of consumption has been a rapidly expanding interdisciplinary field since the 1980's, buit is a field where some very expressive and symbolic forms of consumption and som types of cosumers, like teenagers, have been too much in focus, while other more mudane and everyday aspects heen rather neglected. The paper argues for a greater interest in consumption as an everyday skill, dcusing on the materiality of handling commodities and as an art of household economizing.

Learning to be a consumer is a competence which varies between generations and classes and it is, of coure, highly gendered. A historical perspective may help us to understand the ways in which such competences are developed, changed or reproduced in everyday life, but also how definitions of necessary ad unnecessary consumption change and are used as an ideological weapon against certain groups.

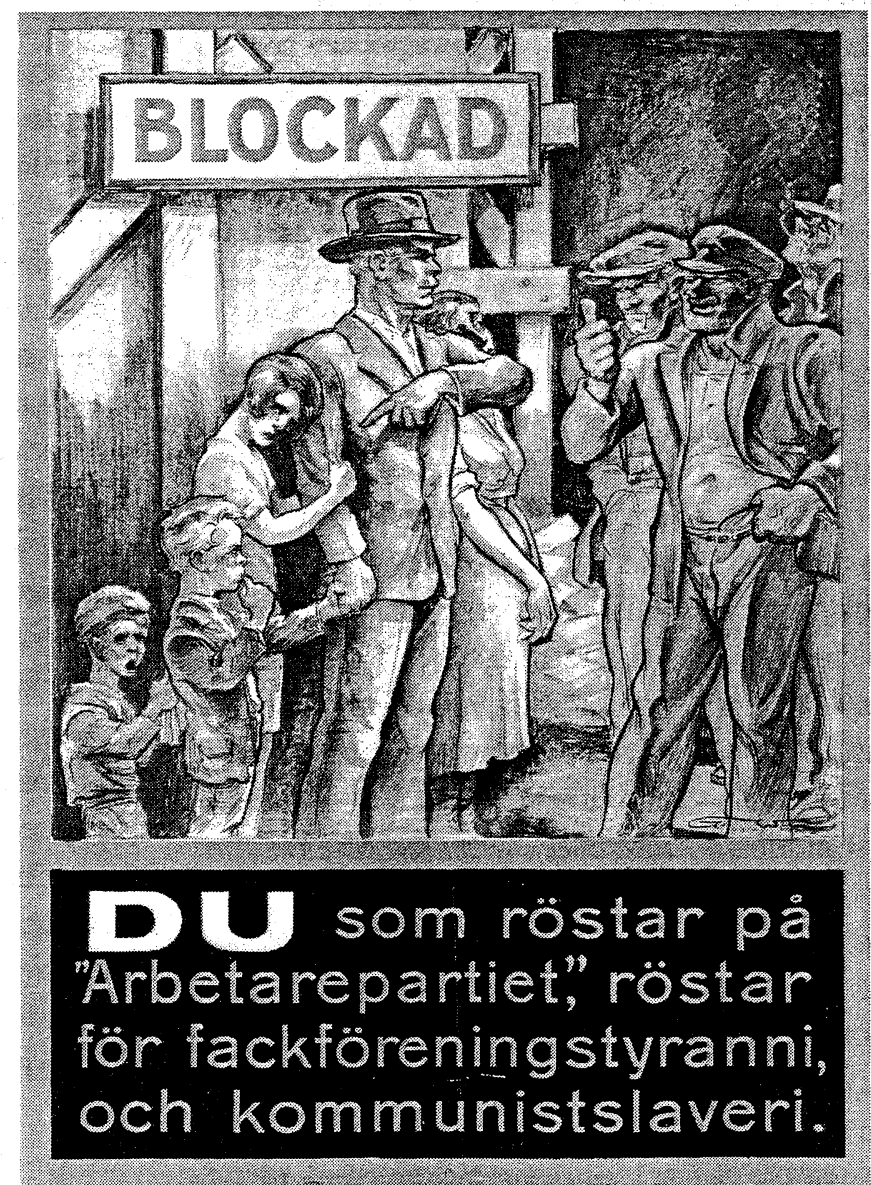

Löfgren - Konsumtion som vardaglig praktik och ideologiskt slagfält 